\title{
AC 2012-3919: INVESTIGATING SWEDISH TEACHER'S APPROACHES TO THEIR TEACHING PRACTICE
}

\author{
Prof. Arnold Neville Pears, Uppsala University
}

Arnold Pears received his B.Sc. and Ph.D. from La Trobe University, Melbourne, Australia, and was a Senior Lecturer there 1991 to 1998 , before moving to Uppsala University, Sweden, to take a position there as Senior Lecturer in 1999, where he has remained. Pears is Associate Professor in computing education research at Uppsala University, and has a strong interest in teaching and learning research in computer science and engineering. He has published more than 25 reviewed articles in international journals in the area and is well known as a computing education researcher through his professional activities in the ACM, and IEEE. His recent articles include discussions of quality in computer science education, "Does Quality Assurance Enhance the Quality of Computing Education?" in Proceedings of the 12th Australasian Computer Science Education Conference, 2010, and models for research driven education in computing, "Conveying Conceptions of Quality through Instruction," in the Seventh International Conference on the Quality of Information and Communications Technology, 2010. He is a Director of CeTUSS (The Swedish National Center for Pedagogical Development of Technology Education in a Societal and Student Oriented Context, http://www.cetuss.se/) and a Reviewer for Computer Science Education Journal, and the ACM SIGCSE and ITiCSE and Koli Calling International Computer Science Education conferences. Pears is currently Steering Committee Chairman of the IEEE Frontiers in Education Conference, and has served as Programme Chair for several other international conferences.

\section{Dr. Judy Sheard, Monash University}

Judy Sheard is an Associate Professor in the faculty of information technology, Monash University. She has had leadership roles both nationally and internationally in the computing education research community. Sheard's main research interests are in student learning behavior and in exploring the web as a new educational medium. She has extensive experience in computing education related projects including several nationally funded projects. Sheard has published more than 100 peer-reviewed papers on IT education and educational technology. She has given three keynote addresses and several invited talks at conferences internationally on computing education topics. Sheard is Co-director of the Computing Education Research Group (CERG) at Monash and immediate Past Chair of the Australasian Chapter of the ACM special interest group in computing education (SIGCSE). She was Programme Chair for the Fourth Australasian Computing Education conference (2000), Co-leader of an ITiCSE 2003 international working group, and Co-organiser of doctoral consortia in 2009, 2011, and 2012. Sheard has more than 22 years experience in teaching programming to undergraduate and post-graduate students. She was awarded the Monash Vice Chancellor's Award for Team-based Educational Development (2002) and School of Computer Science and Software Engineering Excellence Awards (2002 and 2003). 


\title{
Investigating Teacher's Approaches to their Teaching Practice
}

\begin{abstract}
This report develops and analyses the reliability and validity of a Swedish translation of the Trigwell and Prosser Approaches to Teaching Inventory (ATI) using data collected from academics in the Faculty of Technology and Natural Sciences at Uppsala University Sweden.

The first part of the report describes the development and validation of a Swedish translation of the ATI. The Swedish instrument structure is analysed using factor analysis and a two factor model derived that confirms the structure reported earlier by Prosser and Trigwell. The constructs proposed by Prosser and Trigwell are also tested by computing cronbach alphas.

We then stratify the data and perform statistical comparisons attempting to identify statistically significant differences in the subscales of the ATI based on gender, age, role in the organisation, and participation in courses in theory and practice of higher education.
\end{abstract}

\section{Introduction}

The importance of educational quality, and a need to enhance capacity for scholarship in teaching and learning among academics has increased in global importance following the publication of Boyer's book "The priorities of the Professoriate" in 1990 ${ }^{1}$. His description of a fourth scholarship dealing with teaching and inspiring learners to engage in the discipline sparked a worldwide interest in enhancing higher education quality through staff development, and staff involvement in applied education theory across all disciplines.

In Sweden initiatives led by the Higher Education Department have increased interest by University management in systematic assessment of educational quality. At Uppsala University these initiatives are operationalised by the passing of a univeristy wide educational quality initiative (Pedagogiska Programmet). As a part of its response to this general plan for further development of educational quality at Uppsala University, the Faculty of Technology and Natural Science established a higher education development and advisory body "TUR" in 2008. An inventory of existing practices and attitudes to education among academic staff was identified as a priority area in the three year action plan for TUR developed in 2009. 
The Approaches to Teaching Inventory ${ }^{2}$ is an instrument developed by Prosser and Trigwell to provide insight into how University teaching staff view teaching and learning activities associated with their role at the University. This paper describes the results of a project which developed and validated a Swedish language version of the ATI. In addition it summarises results collected using the Swedish survey in the Faculty of Science and Technology at Uppsala Univerity, identifying trends in approach and attitude among academics, drawing on responses from 521 members of academic staff.

The analysis presents overall indicators derived from the ATI instrument, as well as identifying statistically significant differences. The dependent variables studied include age, gender, participation in courses in higher education theory, and function within the organisation. We identify a strong student-centric approach across the entire Faculty of Science and Technology, however there is also a strong focus on teaching for assessment which we believe is linked to the recent emphasis on learning outcomes and examination of student-centric learning outcomes associated with implementing the learning outcomes and other educational values of the Bologna system in Sweden.

The paper is structured as follows. Development of the Swedish version of the ATI is described. This is followed by a summary of the study method and data collection process. The results of factor analysis and reliability measures, including computation of Cronbach's alpha for relevant statistical constructs, are then presented and discussed. An analysis of variations in approach to teaching on the basis of a range of key variables are presented and discussed. Finally we provide conclusions and areas for future exploration.

\section{Background}

The approaches to teaching inventory (ATI) has been developed and refined over the last decade. It has its origins in phenomenographic studies of teachers' attitudes to teaching and learning in the mid 1990's. A description of the developmental history and statistical analysis of the instrument can be found elsewhere ${ }^{2,3}$.

Prosser and Trigwell advance the view that there is a fundamental qualitative difference between a student-centric and teacher-centric view of the learning process ${ }^{3}$, page 408 . They argue that a student centered approach to facilitating learning focuses on the nature of the learning itself, placing the main emphasis on changing student conceptions in relation to the subject matter being studied. In contrast to this a teacher-centric approach may be characterised by a focus on issues related to subject matter content and delivery. This position is supported by the work of several earlier researchers ${ }^{4,5}$, and we have also recent data which supports the existence of these qualitative differences in teacher perception among computer science academics ${ }^{6}$

The initial versions of the ATI included a larger number of items, and scales than the revised version finally proposed in 2006. Initial versions proposed a model which separated intention and strategy into two major scales, comprising four intention sub-scales and three strategy 
sub-scales respectively. After statistical analysis in several stages ${ }^{1}$ they arrived at a final version consisting of nineteen items ranked on a positive scale (1-5), where 1 represents hardly ever true, and 5 nearly always true. All items are positively scored.

The factor analysis conducted on aggregated data from a number of studies was unable to demonstrate the viability of the originally proposed scales. The final version consists of two major scales Conceptual Change/Student Focused (CCSF) and Information Transmission/Teacher Focused (ITTF), representing the major qualitative distinction argued for in Prosser and Trigwell's earlier work. The English language items that comprise each of the scales are reproduced in appendix B.

To assist us in relating the ATI scales to learning activity it is useful to relate them to a model of learner development and the learning process. Figure 1 adapted from Entwistle ${ }^{7}$ integrates two perspectives on the learning process and relates them to learner development of understanding and identity. We argue that a teacher's ability to facilitate student development in both these dimensions is enhanced if they adopt a conceptual change/student-centric approach in their role as teachers.

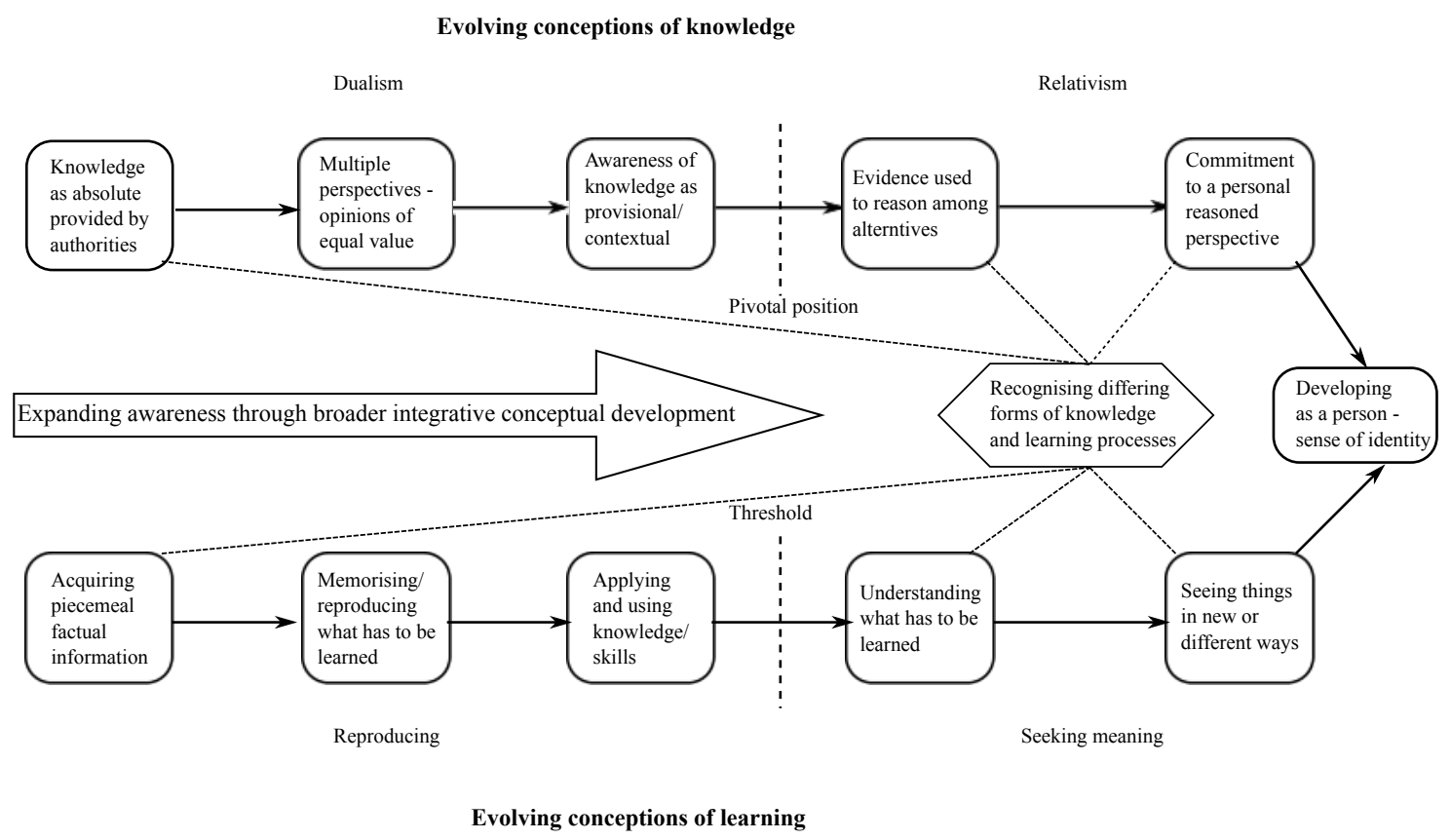

Figure 1 Entwistle's integrative model of learner development

This viewpoint is supported by research of $\mathrm{Kember}^{8}$, who studies the impact of attitudes and expectations on the nature and outcomes of the teaching and learning process.

The ATI has been used in several investigations of teaching practices and outcomes in higher education. Gibbs and Coffey ${ }^{9}$ used the ATI in conjunction with other instruments in a study that attempts to link teacher training in higher education theory to improved learning outcomes for students. Similar studies have also been conducted in Holland and Finland ${ }^{10}$.

\footnotetext{
${ }^{1}$ See Prosser and Trigwell ${ }^{3, \text { pages } 408,409}$
} 


\section{Method}

\section{Survey Development}

Administration of the ATI survey instrument to non-English speakers is fraught with problems. The manner in which some of the questions are phrased is unfamiliar to non-native speakers, and this can confuse respondees and reduce the consistency of responses. Answering a survey in a second or third language can also produce inconsistencies that affect the validity of statistical constructs. During the initial phase of our project it was decided that a Swedish language version of the ATI would be be developed and validated.

The Swedish language version of the ATI was developed directly from the version published by Prosser and Trigwell ${ }^{3}$ page 418-419. The English version of the ATI was translated into Swedish by the first author and a close colleague who was a native Swedish speaker. The resulting questionaire items were then translated back into English by another Swedish colleague and reviewed by the development group. In cases where the English versions differed significantly we reviewed and discussed the Swedish version and made revisions to address the alternative interpretation inherent in the formulation of the Swedish statement.

After this the survey was distributed to the eight TUR members and further input solicited. In this phase the phrasing of some items was further adjusted to obviate misinterpretation. Additional demographic questions were also added at this stage to capture richer information on participant's background experience and prior courses in theory of higher education. The final survey instrument is reproduced as Appendix A.

\section{Validation}

We conducted a structural analysis of the Swedish version of the ATI using similar statistical procedures on our final data set to those employed by Prosser and Trigwell. The analysis was conducted in SPSS. A Bartlett's test of sphericity was significant at $\mathrm{p}<0.05$ and the KaiserMeyer-Olkin Measure of Sampling Adequacy test was 0.764, indicating that the dataset was factorable.

Several models were fitted to the data using Principal Axis Factoring. The rotation method was Varimax rotation with Kaiser Normalization. An initial factor analysis yielded four factors with eigenvalues greater than 1.0. An examination of the scree plot showed a point of inflection between the second and third factors indicating that a two factor solution should be investigated. The two factor solution yielded interpretable results and after comparisons with three and four factor solutions we concluded that this was the best fit (in common with Prosser and Trigwell ${ }^{3}$ ). Final rotated loadings for items in the two factor model are shown in figure 2. The percentage of variance for each factor are $18.86 \%$ and $13.95 \%$. Items in the ITTF and CCSF scales shown in figure 2 are consistent with those proposed by Prosser and Trigwell with the exception of items ITTF5 and ITTF1. 


\begin{tabular}{||l|c|c||}
\hline Item & Factor 1 & Factor 2 \\
\hline ITTF1 & 0.208 & 0.217 \\
ITTF2 & & 0.575 \\
ITTF3 & & 0.658 \\
ITTF4 & & 0.416 \\
ITTF5 & & \\
ITTF6 & & 0.522 \\
ITTF7 & & 0.379 \\
ITTF8 & & 0.271 \\
\hline CCSF1 & 0.458 & \\
CCSF2 & 0.541 & \\
CCSF3 & 0.393 & \\
CCSF4 & 0.636 & \\
CCSF5 & 0.465 & \\
CCSF6 & 0.553 & \\
CCSF7 & 0.324 & \\
CCSF8 & 0.662 & \\
\hline
\end{tabular}

Figure 2 Rotated factor matrix.

The Cronbach Alpha was computed for both scales as a measure of internal consistency. In the CCSF scale we obtain a value of $\alpha=0.73$, in comparison to Prosser and Trigwell $\alpha=0.74$. A value of alpha above 0.7 is considered quite good, though over 0.75 is desirable. Based on these measures we concluded that the CCSF scale was reliable for the Swedish instrument. For the ITTF scale we obtained $\alpha=0.59$, which was improved to $\alpha=0.63$ by excluding the non-loading item ITTF5 from the construct. For this scale Prosser and Trigwell reported $\alpha=0.66$, which is slightly stronger than our result. However both these results are weaker than is generally desirable, and more work could be applied to refining the items in this scale to obtain higher internal consistency in responses.

In the ITTF scale item 5 does not load on either factor, and item 1 loads weakly on both fac-

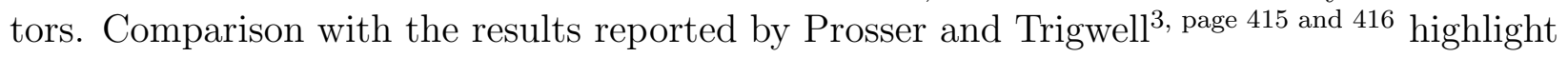
difficulties with item ITTF5, where our results show no loading on either factor.

"I design my teaching in this subject with the assumption that most of the students have very little useful knowledge of the topics to be covered."

In contrast to their results we have a fairly strong loading on ITTF6.

"In this subject I concentrate on covering the information that might be available from a good textbook."

We believe that this may reflect some differences in learning culture, though both our and Prosser and Trigwell's studies draw on a significant number of responses from Swedish academics. The difference in our study is that all responses were collected from a single faculty 
at a single university over the period of a year, while Prosser and Trigwell's data was collected from a wider range of contexts over a considerably longer period of time.

In addition the item ITTF1

"I feel it is important that this subject should be completely described in terms of specific objectives relating to what students have to know for formal assessment items."

loads weakly on both factors. This can be explained by the Swedish educational context and recent reforms in higher education that have empahsised constructive alignment, and the importance of aligning instruction and assessment with desired learning outcomes at the course level. This institutional emphasis can mean that this item is seen as universally important by all staff, thus explaining the weak positive loading on both factors.

\section{Descriptive Statistics}

The survey was sent to 1624 e-mail addresses obtained from the central address database of employees of the Faculty of Technology and Natural Sciences at Uppsala University. Three reminders were sent to participants over the course of 2006 and 2007 resulting in 515 complete responses. Background information was collected for all participants. The graphs in figures 3 to 7 show the distribution of responses in a range of categories.

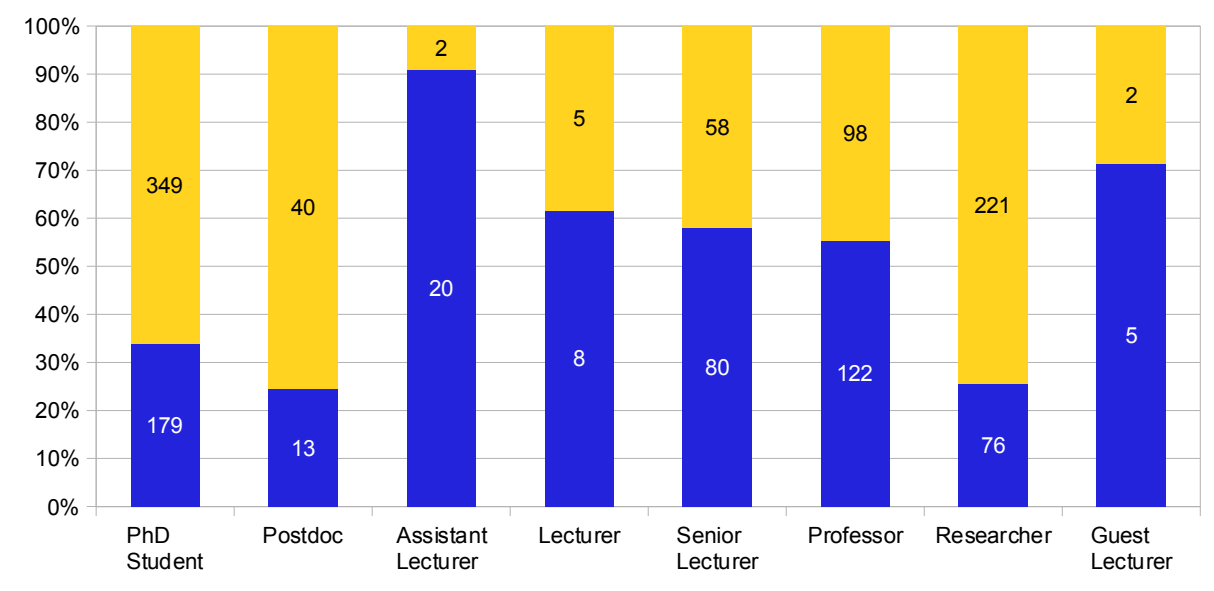

Figure 3 Distribution of Respondents by Employment Category

The dominant group of respondents are PhD students $(\mathrm{N}=179)$, with lecturers $(\mathrm{N}=80)$ and professors $(\mathrm{N}=117)$ also well represented. The percentatges of respondents for all categories of employment are shown in 3 The large number of responses from $\mathrm{PhD}$ students might intitally seem unusual, howver, PhD students are actively involved in teaching in Swedish 
Universities and many also take courses in higher education theory as a part of their $\mathrm{PhD}$ studies.

The number of responses from professors vs lecturers is also interesting, since professors are significantly outnumbered by lecturers in the faculty. This means that professors are more highly represented than lecturers in our sample.

Distribution of responses by age is shown in figure 4. Approximately fifty percent of respondents are aged 25 to 40 years of age, which is consistent with the large number of $\mathrm{PhD}$ students.

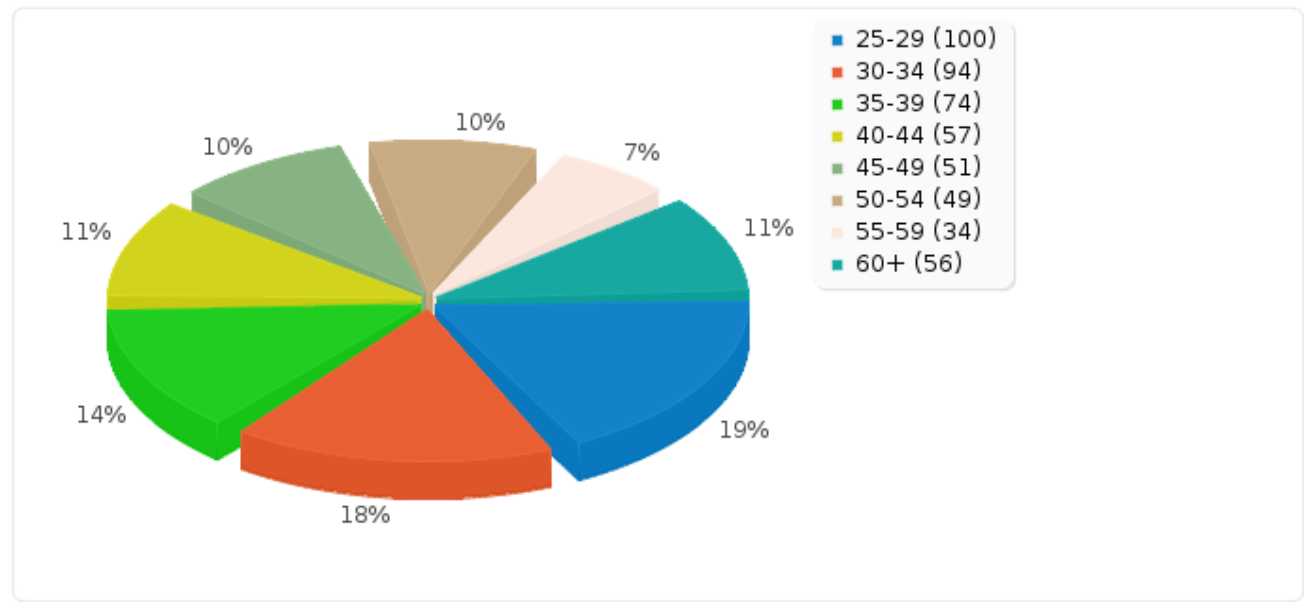

Figure 4 Distribution of Respondents by Age

The gender division in the sample is shown in figure 5. Not unexpectedly women constitute only thirty percent of the sample. This is not unusual in higher education in science and technology, where women have traditionally been under-represented.

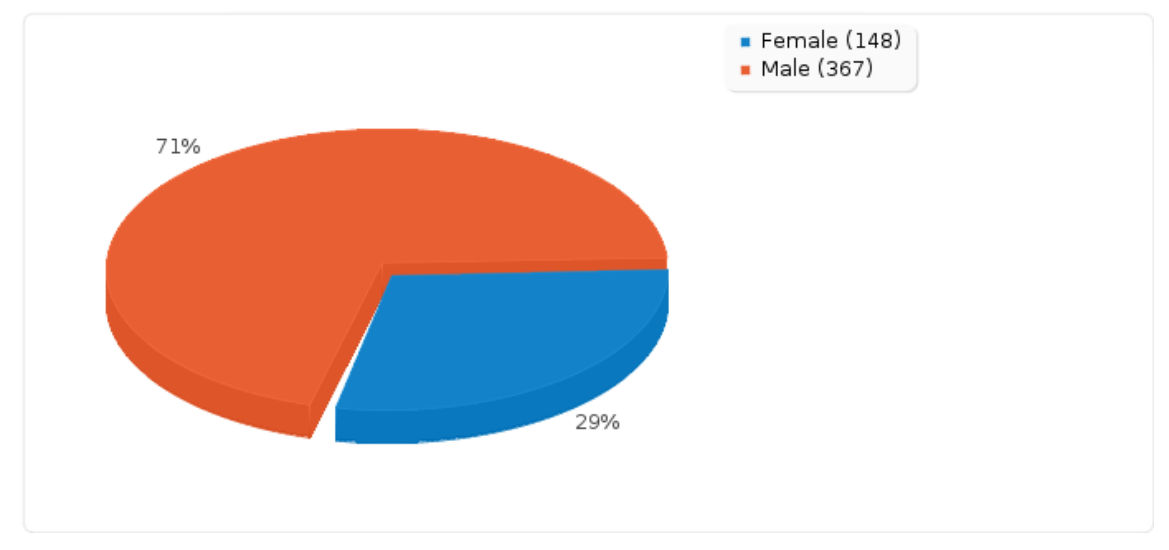

Figure 5 Distribution of Respondents by Gender

We asked respondents to identify what year levels of courses they taught. The data seems to include good representation of views from teachers operating at all year levels from first year to $\mathrm{PhD}$ student courses and supervision. Figure 6 summarises the number of respondents 
teaching courses in each of the academic levels in 2009. Staff were able to nominate more than one year level in reponse to this item, so the responses also indicate that many respondents were regularly engaged in teaching in several year levels.

To gain an impression of the level of staff background in education theory we asked what development courses in theory of higher education respondents might have undertaken. Interestingly a majority of staff who responded to the survey had taken one or more courses, as shown by the percentage coverage in figure 7. Most highly represented was the basic course in theory of higher education (University teaching, $\mathrm{N}=318$ ) followed by a course for supervisors of research students (Research supervision, $\mathrm{N}=158$ ). Quite a few respondents had also taken a course in science and technology education offered annually by the Faculty of Science and Technology (Subject didactics, $\mathrm{N}=59$ ) or considered themselves to have other relevant courses in education (Other, $\mathrm{N}=197$ ).

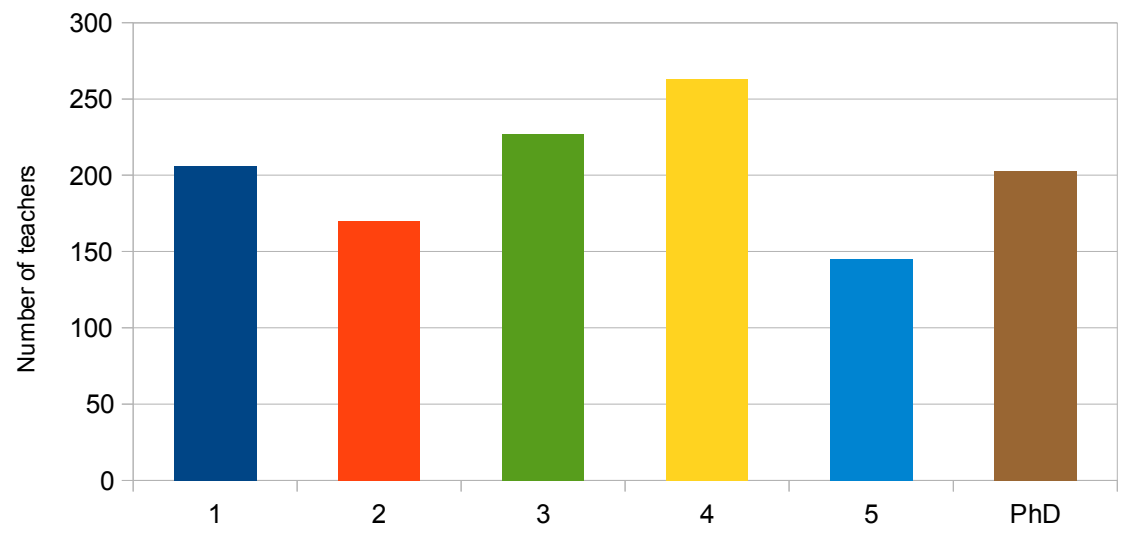

Figure 6 Distribution of Respondents by Teaching Year-level

Overall the educational theory background of the respondents is quite high, reflecting the emphasis on in service training in Swedish higher education over the last ten years. It is now standard practice that academic appointments at the grade of lecturer and above require candidates to have ten weeks of formal coursework in educational theory and practice for higher education, or documented equivalent professional experience.

\section{Results and Discussion}

The ATI instrument provides a basis for exploring relationships and shifts in conceptions of teaching and learning in the two major dimensions of conceptual change with a student focus, and information transmission where the focus is more on the teacher and the role of the teacher as a repository and mediator of knowledge. The absolute scale values are difficult to interpret directly and Prosser and Trigwell advise against direct use of the scale for comparison of teacher approaches. Instead the ATI is usually employed to explore longditudinal 


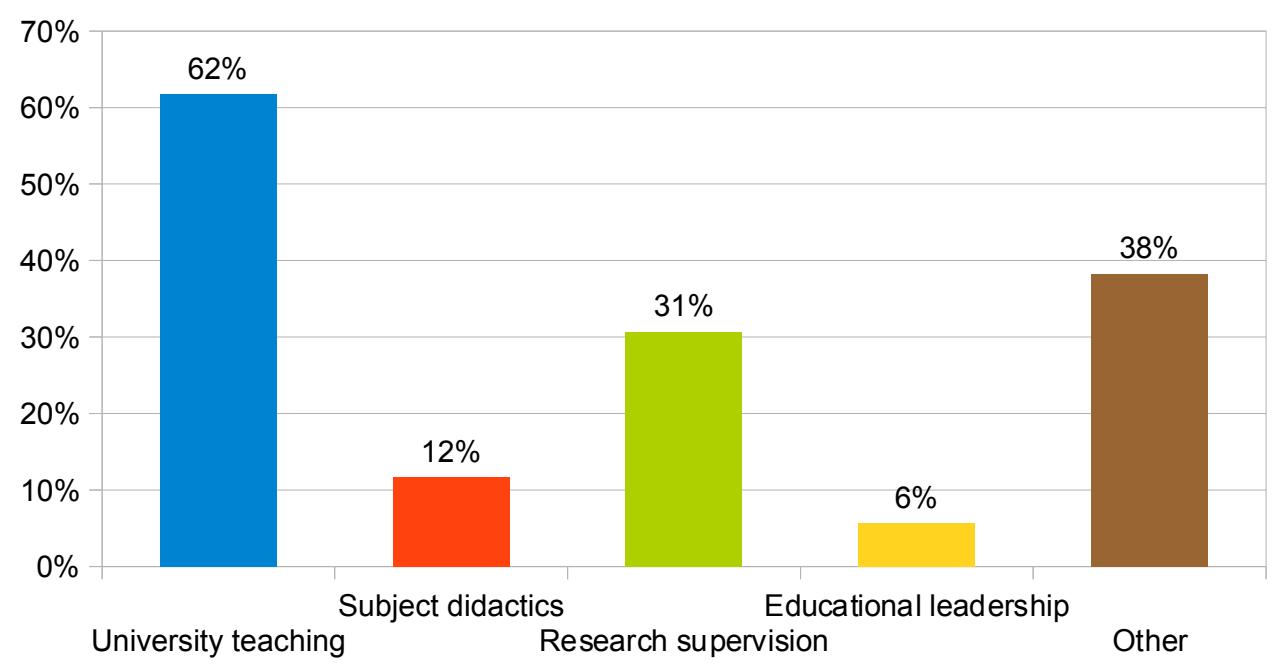

Figure 7 Distribution of Respondents by Pedagogical Education

changes in attitude in the same setting, rather than as a direct indicator of teachers attitudes to teaching practice.

Using the demographic data summarised in the previous section we have explored the data to identify statistically significant differences between categories of survey respondent for the initial survey. These data provide indications of the efficacy of current staff development initiatives, as well as revealing differences in approach for between staff at different academic levels. The ultimate aim of the project is to compare the 2009/2010 data with data that will be collected in 2012/2013, which can be expected to provide indications of shifts in attitude and practice resulting from university pedagogy and educational development initiatives.

In conducting our initial analysis the Mann-Whitney test has been used for gender related data, and Kruskal-Wallis was used in all other cases where we where we were comparing more than two response categories. The goal was to identify trend in Mean Rank within a category. E.g. Student-centricity tends to be valued more highly as you move between employment categories from Researcher, to PhD student, and then Lecturer to Professor.

\section{Gender differences}

A gender based comparison of responses reveals a number of interesting results. Based on item ITTF1, women are significantly more likely to value detailed course description than men $(\mathrm{U}=24435.5, p<0.05)$.

ITTF1: I feel it is important that this subject should be completely described in terms of specific objectives relating to what students have to know for formal assessment items 
Men, on the other hand, are significantly more content focused than their female counterparts, and more likely to emphasise their role as a subject expert, ranking significantly higher on items ITTF3 ( $\mathrm{U}=22233.5, p<0.05)$ and ITTF4 $(\mathrm{U}=21598.5, p<0.05)$.

ITTF3: I think an important reason for running teaching sessions in this subject is to give students a good set of notes ITTF4: I feel that I should know the answers to any questions that students may put to me during this subject

In general men rank significantly higher on the ITTF scale than women, when items 1 and 5 are excluded $(\mathrm{U}=23148.5, p<0.05)$. This implies that women appear more likely to focus on the formal requirements of the course, making sure that the course conforms with university regulations and proceedures. Men appear to be more inclined to view teaching activity in terms of information transmission activities, such as giving students a good set of notes. The higher response among men on ITTF4 implies that men might have a greater personal investment in being percieved as experts in the learning context.

\section{Differences by Job Classification}

Statistically significant trends in the data have also been identified in a number of areas between teachers of different levels of experience. Typically professors and lecturers can be assumed to have more extensive teaching experience than PhD students and research staff. Our data also shows that professors and lecturers often have significantly different views than $\mathrm{PhD}$ students and Researchers in regard to teaching and learning activities. Our data shows statistically significant differences in the CCSF scale for items 1, 5, and 7, and also in ITTF item 4.

Item CCSF1 deals with creating opportunity in the learning context for students to demonstrate changes in their conceptual framework, and manner of understanding the knowledge area addressed by the course.

"I feel that the assessment in this subject should be an opportunity for students to reveal their changed conceptual understanding of the subject."

Emphasis on allowing students to express changed conceptual understanding is valued least by $\mathrm{PhD}$ students, followed by Researchers, Lecturers and most by Professors. This is not unexpected considering the context of the learning situations in which these categories of employees normally find themselves. One conclusion that can be drawn from this is that it might be worth investigating ways to increase the understanding among $\mathrm{PhD}$ students of the value of letting students express and discuss their conceptions in relation to the topics being studied.

This tendency to be less interactive and explorative in teaching and learning settings also emerges in a similar pattern of responses to item CCSF5, which concerns the level of conversation associated with student interaction. 
"In my interactions with students in this subject I try to develop a conversation with them about the topics we are studying-"

Developing opportunity for discourse during interaction with students is, again, valued least by $\mathrm{PhD}$ students, followed by researchers, professors and lecturers $\left(\chi^{2}(2, \mathrm{~N}=493)=29.27\right.$, $p<0.05)$. The relative position of professors and lecturers is reversed with respect to CCSF1, but the difference is relatively small. The primary division is between PhD students and researchers on the one hand, and lecturers and professors on the other $\left(\chi^{2}(2, \mathrm{~N}=487)=\right.$ 23.11, $p<0.05)$.

The trend in tendency to use of difficult examples to provoke debate (CCSF7) is Researcher(highest), Lecturer, Professor, PhD student(lowest), $\left(\chi^{2}(2, \mathrm{~N}=488)=12.10, p<\right.$ 0.05). Here, it might be expected that we observe differences, since the role of these categories of educator are rather different in most academic settings.

Academic status and credibility is an important aspect of academic teaching, this is reflected in differences in perception in relation to ITTF4.

ITTF4: I feel that I should know the answers to any questions that students may put to me during this subject

Being able to always answer questions (ITTF4) is ranked Professor, Lecturer (high) vs Researcher and PhD student (low) $\left(\chi^{2}(2, \mathrm{~N}=487)=13.12, p<0.05\right)$. The implications of this trend are that Professors and Lecturers, with their greater responsibility for student education, seem to feel greater responsibility for being able to answer questions on the spot. Researchers and $\mathrm{PhD}$ students are typically responsible for smaller and more constrained elements of classroom teaching, and thus might be expected to feel less responsibility for answering general questions about the topics covered.

\section{Pedagogical Education}

The impact of professional development of staff through participation in education and pedagogy courses is also an important result of this initial study. There is a clear, and statistically significant, trend toward increased CCSF scores among staff who have taken courses in theory of teaching and learning in higher education, the biggest impact appears to be a course offered by the Faculty of Science and Technology in Applied Educational Theory and Practice. There is also a significant trend in decreasing value placed on ITTF scale with increasing pedagogic education.

\section{Conclusions}

The ATI survey conducted during Autumn 2009 and Spring 2010 in the Faculty of Science and Technology at Uppsala University provides an excellent basis for future assessments of 
shifts in approach to teaching within the faculty teacing corps.

While the ATI is not intended to be used directly as a measurement instrument, we have been able to identify some clear trends that provided a point of departure for future pedagogical development work during 2011 and 2012. In particular, the positive correlation between the faculty courses in didactics and increased conceptual change/student-centric focus omong teaching staff provides strong agruments for continuing these intiatives.

While it might be argued that only staff who already have a strong interest in teaching and learning take these courses, it is clear that the result is a more aware and well educated teaching cohort. Academic staff who have taken these courses have a wider range of pedagogical tools to apply to their teaching, and a richer pedagogical understanding, both of which contribute significantly to ensuring that Uppsala University delivers education of the highest quality.

Work on this project continues and a further data collection exercise is planed for the Autumn of 2012, after which detailed comparisons can be made to identify shifts in teaching and learning perception within the Faculty.

\section{Bibliography}

[1] E. Boyer, Scholarship Reconsidered: Priorities of the Professoriate. Hillsdale, NJ: Carnegie Foundation for the Advancement of Teaching and Josey-Bass, 1990, 1997.

[2] K. Trigwell and M. Prosser, "Development and use of the approaches to teaching inventory," Educational Psychology Review, vol. 16, no. 4, pp. 409-424, 2004. [Online]. Available: http://www.springerlink.com/content/v67702j33t854r35/

[3] M. Prosser and K. Trigwell, "Confirmatory factor analysis of the approaches to teaching inventory," British Journal of Educational Psychology, vol. 76, pp. 405-419, 2006.

[4] E. Martin, M. Prosser, K. Trigwell, P. Ramsden, and J. Benjamin, "What university teachers teach and how they teach it." Intructional Science. Special issue: Teacher Thinking, Beliefs and Knowledge in Higher Education, vol. 28, no. (5-6), pp. 387-412, 2000 .

[5] David and Kember, "A reconceptualisation of the research into university academics' conceptions of teaching," Learning and Instruction, vol. 7 , no. 3, pp. 255 - 275, 1997. [Online]. Available: http://www.sciencedirect.com/science/article/pii/S095947529600028X

[6] A. Pears, S. Fincher, R. Adams, and M. Daniels, "Stepping stones: Capacity building in engineering education," in Frontiers in Education Conference, 2008. FIE 2008. 38th Annual, Oct. 2008, pp. 1-6.

[7] N. Entwistle, "Conceptions of Learning and the Experience of Understanding: Thresholds, Contextual Influences, and Knowledge Objects," in Re-framing the conceptual 
change approach in learning and instruction, S. Vosniadou, A. Baltas, and X. Vamvakoussi, Eds. Amsterdam, The Netherlands: Elsevier, 2007, ch. 11.

[8] D. Kember, "Beliefs about knowledge and the process of teaching and learning as a factor in adjusting to study in higher education," Studies in Higher Education, vol. 26, no. 2, pp. 205-221, February 2001. [Online]. Available: http://www.tandfonline.com/doi/abs/10.1080/03075070120052116

[9] G. Gibbs and M. Coffey, "The Impact Of Training Of University Teachers on their Teaching Skills, their Approach to Teaching and the Approach to Learning of their Students," Active Learning in Higher Education, vol. 5, no. 1, pp. 87-100, 2004. [Online]. Available: http://alh.sagepub.com/cgi/content/abstract/5/1/87

[10] L. Postareff, S. Lindblom-Ylänne, and A. Nevgi, "The effect of pedagogical training on teaching in higher education," Teaching and Teacher Education, vol. 23, no. 5, pp. 557 571, 2007. [Online]. Available: http://www.sciencedirect.com/science/article/B6VD84MV19V3-1/2/cc930e32da15f065af45d6ea4428d84a 


\section{Appendix A: Swedish ATI Items}

Skala: införmationsöverföring/lärarefocusserad (ITTF)

Subskala: intention att överföra information

Jag anser att det är viktigt att kursen är fullständigt beskriven avseende de specifika lärandemål som studenterna kommer att bli examinerade på.

Jag tycker att det är viktigt att redovisa många begrepp och mycket fakta så att studenterna vet vad de måste lära sig under kursen.

Jag tycker att en viktig aspekt av schemalagd undervising i min kurs är att se till att studenterna får bra föreläsningsanteckningar.

Jag anser att jag borde kunna svara på alla kursinnehållsfrågor studenterna kan tänkas ställa under kursens gång.

Subskala: lärarecentrerad strategi

När jag planerar min undervisning i denna kurs utgår jag ifrån att de flesta av studenterna kommer att ha mycket litet relevanta förkunskaper.

I min kurs fokuserar jag på att gå igenom innehållet som kan återfinnas i en bra lärobok.

Jag lägger upp min kurs på ett sätt som ska hjälpa studenterna att klara den formella examinationen.

På den här kursen ger jag studenterna endast den information de behöver för att klara den formella examinationen.

Skala: konceptuellförändring/studentcentrerad (CCSF)

ATI04

ATI11

ATI13

ATI01

ATI07

ATI10

ATI12

\section{Subskala: konceptuellförändring i fokus}

Jag tycker att examinationen i kursen ska ge studenterna möjlighet att visa hur deras förståelse för ämnet har förändrats.

Jag uppmuntrar mina studenter att omstrukturera sina nuvarande kunskaper enligt det nya tankesätt om ämnet som de utvecklar under kursens gång.

Jag anser att det är bättre för mina studenter att de skapar egna anteckningar jämfört med att de bara skriver ner det jag skriver på tavlan.

Jag anser att mycket undervisningstid ska användas till att diskutera och utmana studenternas egna idéer kring ämnet.

Subskala: studentcentrerad strategi

När jag interagerar med studenterna på min kurs så försöker jag skapa en dialog med dem om de tema och de begrepp som ingår i kursen.

Jag avsätter en del undervisningstid så att studenterna ska få tillfälle att diskutera sinsemellan de svårigheter de möter under kursens gång.

Jag använder svåra eller oklara exempel i min undervisning för att provocera fram diskussioner.

Jag skapar möjligheter för mina studenter på kursen att diskutera förändringar i deras förståelse för ämnet. 


\section{Appendix B: English ATI Items}

Scale: Information transmission/teacher-focused (ITTF)

Item no.

Subscale: Information transmission intention items

I feel it is important that this subject should be completely described in terms

ATI02

of specific objectives relating to what students have to know for formal assessment items

I feel it is important to present a lot of facts to students so that they know what they have to learn for this subject

I think an important reason for running teaching sessions in this subject is to give students a good set of notes

I feel that I should know the answers to any questions that students may put to me during this subject

Subscale: Teacher-focused strategy items

I design my teaching in this subject with the assumption that most of the students have very little useful knowledge of the topics to be covered

In this subject I concentrate in covering the information that might be available from a good textbook

I structure this subject to help students to pass the formal assessment items

When I give this subject, I only provide the students with the information they will need to pass the formal assessments

Scale: Conceptual change/student-focused (CCSF) approach

Item no.

Subscale: Conceptual change intention items

I feel that the assessment in this subject should be an opportunity for

ATI05

students to reveal their changed conceptual understanding of the subject

I encourage students to restructure their existing knowledge in terms of the new way of thinking about the subject that they will develop

I feel that it is better for students in this subject to generate their own notes rather than always copy mine

I feel a lot of teaching time in this subject should be used to question students' ideas

Subscale: Student-focused strategy items

In my interactions with students in this subject I try to develop a conversation with them about the topics we are studying

I set aside some teaching time so that the students can discuss, among themselves, the difficulties that they encounter studying this subject

In teaching sessions for this subject, I use difficult or undefined examples to provoke debate

I make available opportunities for students in this subject to discuss their changing understanding of the subject 